\title{
A perindítás megváltozott szabályai a polgári perrendtartás első novelláris módosítása alapján Endrédy András*
}

\begin{abstract}
Magyarország megújult perjogi kódexe, a polgári perrendtartásról szóló 2016. évi CXXX. törvény 2018. január 1-én lépett hatályba. Közel két éves gyakorlati alkalmazása után napvilágot látott elsó átfogó módositása. Jelen tanulmány a perindítással összefüggésben vizsgálja meg a módosított szabályozást elsödlegesen abból a szempontból, hogy alkalmas-e a jogalkotói célkitüzések megvalósítására. Bemutatásra kerülnek a keresetlevél kötelezö tartalmi elemeit, a keresetlevél visszautasítási okokat, illetve a fizetési meghagyásos eljárásból perré alakult eljárásokat érintő reformok.

Kulcsszavak: polgári eljárásjog, Pp. novelláris módositása, perindítás, keresetlevél visszautasitása, a fizetési meghagyásos eljárással összefüggő perek

Changed rules for filing of action under the first amendment to the Code of Civil Procedure The renewed Code of Civil Procedure of Hungary, Act CXXX of 2016 on Civil Procedure, the law entered into force on 1 January 2018. After nearly two years of practical application, its first comprehensive amendment, the 2020 CXIX. Act CXXX of 2016 on the Code of Civil Procedure amending the law. In the context of litigation, the present study examines the amended legislation primarily in terms of its suitability to achieve the legislative objectives. The reforms concerning the mandatory content of the application, the grounds for rejecting the application and the proceedings that have evolved from an order for payment procedure are presented.
\end{abstract}

Keywords: civil procedure law, comprehensive amendment of Code of Civil Procedure, initiation a civil action, mandatory elements of claim, lawsuits related to the order for payment procedures

DOI: $10.32980 / M J S z .2021 .1 .955$

\section{Bevezető gondolatok}

z elmúlt évtizedekben a polgári perrendtartások újrakodifikálásának lehettünk Q tanúi Európa-szerte, melynek alapvető indoka rendre az volt, hogy a polgári pereket szabályozó joganyag felett „eljárt az idő", a gyakorlatban a hatékonyság csökkenése volt megfigyelhető. Új polgári perrendtartási kódexe lett például Romániának, Bulgáriának, Szlovéniának, Lettországnak, Litvániának, Oroszországnak, Észtországnak a rendszerváltást követően, de számos nyugateurópai ország is alapjaiban reformálta meg a polgári pereket szabályozó eljárásjogi

\footnotetext{
* Közjegyző
} 
törvényét, köztük Svájc, Spanyolország és Portugália. ${ }^{1}$

Magyarország új polgári perrendtartásának kodifikációja is hosszú évtizedek óta napirenden volt, a régi $\mathrm{Pp}^{2}{ }^{2}$ 1952-re datálódott, ezért régi adósságának törlesztését kezdte meg az igazságügyi kormányzat 2013-ban, amikor elkezdődött az új polgári perrendtartásról szóló törvény előkészítése. A jogalkotási folyamat 2016 év végén sikerrel végződött, az Országgyülés elfogadta a polgári perrendtartástól szóló 2016. évi CXXX. törvényt (a továbbiakban: Pp.), mely 2018. január 1-jétől váltotta fel a több mint 60 éves pályafutású 1952-es $\mathrm{Pp}-\mathrm{t}$. Az új Pp. rendelkezéseit csak a hatálybalépése után indult ügyekben kell alkalmazni. ${ }^{3}$

Mind a jogtudomány, mind a jogalkalmazók javaslatai beépítésre kerültek az új perrendtartásba, annak előkészitését a szakmai nyitottság és párbeszéd jellemezte, mely folyamatban az Igazságügyi Minisztérium központi szerepet játszott többek között azzal, hogy közvetítette azon szakemberek meglátásait, akik a perjogi kódex megszületésén dolgoztak, konferenciákon és bizottsági üléseken vettek részt, amely folyamat végül a törvény megalkotásához és hatályba lépéséhez vezetett. Valamennyi alapvető dogmatikai megújuláson, reformon átesett szabályozásnál megfigyelhető, hogy a gyakorlati alkalmazás terén viták alakulnak ki, ahogy több európai országban még évekkel az új perrendtartás elfogadása után is élénk szakmai diskurzus folyik a bevezetett rendelkezések hatékonyságáról ${ }^{4}$, és nem ritkák a reformok eredményességével kapcsolatban megfogalmazott kételyek sem. Ez jellemzi a Pp. alkalmazása körül kialakult szakmai diskurzust is hazánkban.

A Pp. hatályba lépését követően a joggyakorlatban és a jogértelmezésben egyes szabályokat, illetve néhány jogintézményt érintően eltérő álláspontok alakultak ki, illetve a törvény gyakorlati alkalmazása bizonyos pontokon nem kívánt eredményre vezetett, melynek hatására megszületett a 2020. évi CXIX. törvény a polgári perrendtartásról szóló 2016. évi CXXX. törvény módosításáról (a továbbikban Novella vagy Pp. Novella), mely az első átfogó, novelláris módosítását jelenti eljárásjogi kódexünknek. ${ }^{5}$ Figyelemmel arra, hogy a Pp. hatályba lépése óta közel két év telt el, a legtöbb gyakorlati tapasztalat a perindítás kapcsán volt kimutatható és dokumentálható. Erre figyelemmel is a perindítási szakhoz kapcsolódó változások alapjaként a Novellához fúzött miniszteri indokolás több ponton is indokként hoz fel a joggyakorlatban korrigálandó kérdéseket.

1 Wopera Zsuzsa: $\mathrm{Az}$ új polgári perrendtartás karakterét adó egyes megoldások európai összehasonlításban; ADVOCAT(2017) különszám 2. o.

2 1952. évi III. törvény a polgári perrendtartásról, a továbbiakban: 1952-es Pp.

3 Wopera Zsuzsa: Az új polgári perrendtartás karakterét adó egyes megoldások európai összehasonlításban; ADVOCAT (2017) különszám 2. o.

${ }^{4}$ Kengyel Miklós: $A$ bírói hatalom és a felek rendelkezési joga a polgári perben, Budapest, Osiris, 2003. 140-147. o.; Magyary Géza: Magyar perjogi reformmozgalmak. Magyary Géza öszszegyüjtött dolgozatai a polgári eljárás, a magánjog és a kereskedelmi jog köréböl, I. kötet, Budapest, MTA, 1942. 16. o.

${ }^{5}$ A 2020. évi CXIX. törvény nem az első módosítása a Pp.-nek, az eljárásjogi törvény hatályba lépése óta hét kisebb módosításon esett át. Ezek a kisebb módosítások nem változtatták azonban meg a Pp. alapvető szerkezetét, a lényegesebb eljárásjogi szabályokat (mint például a keresetlevél tartalma, keresetlevél visszautasítása, tárgyalás stb.), és a módosított szakaszok száma sem volt olyan nagyságrendü, amely alapján a jogalkalmazó és tudományos közösség szerint novelláris módosításként definiálta volna. Udvary Sándor: Az első Pp. novella hatása az elsőfokú eljárásra; Jogtudományi Közlöny (2021) 3. 131. 0. 
Jelen tanulmány a terjedelmi korlátokra tekintettel nem vállalkozhat arra, hogy valamennyi novelláris módosítást bemutassa, elemezze, ezért ehelyütt szükséges megszorításokat tennünk. Figyelemmel arra, hogy közjegyzőként dolgozom, egyéni megfontolások miatt csak azokat a módosított rendelkezéseket veszem górcső alá, melyek a perindításhoz, a keresetlevél kötelező tartalmi elemeihez, illetve a keresetlevél visszautasításához kapcsolódnak. Teszem ezt kettős megfontolásból: egyrészről ezen a területen mutathatók be a joggyakorlatban kialakult korrigálandó tendenciák, ellentétes joggyakorlatok és némi jogbizonytalanság, másrészről csak ezek ismeretében érthető́k meg a fizetési meghagyásos eljárással összefüggő pereket érintő módosítások, mely alapvetően illeszkedik a közjegyzői munkámhoz, figyelemmel arra, hogy a fizetési meghagyásos eljárás a közjegyző hatáskörébe tartozó nemperes eljárás. Azt is fontos rögzíteni, hogy jelen tanulmány nem vállalkozik arra sem, hogy csokorba gyüjtse azokat a koncepcionális jellegü változásokat, melyek dogmatikai szinten következtek be a Pp. Novella hatására.

\section{A Pp. átfogó módosításának általános indokai}

A Pp. módosítás általános célkitűzése a szabályozás finomítása, egyszerüsítése és rugalmasabbá tétele volt. A jogalkotó támaszkodott a Pp. hatályosulásának gyakorlati tapasztalataira, a Pp. egyes rendelkezéseihez kapcsolódó alkotmánybírósági döntésekben ${ }^{6}$ foglaltakra, és nem utolsó sorban a jogalkalmazó szervek visszajelzéseire. Kiemelt jogalkotói célkitüzés volt a jogkeresők bírósághoz fordulásának megkönnyítése úgy, hogy továbbra is biztosíthatók legyenek a koncentrált per feltételei, az osztott perszerkezet előnyei érvényesülhessenek, és a felek önrendelkezési joga is domináns maradjon.

A törvény-módostás tartalmának kialakításához a hivatásrendek által tett javaslatokon kívül alapul szolgáltak a Kúria új Pp. kérdéseivel foglalkozó konzultációs testületének állásfoglalásai, a Civilisztikai Kollégiumvezetők Országos Tanácskozásának Pp.-t érintő ajánlásai, továbbá a Kúriának a keresetlevél visszautasításának vizsgálata tárgykörében felállított joggyakorlat elemző csoportjának összefoglaló véleményében tett megállapítások, valamint az Igazságügyi Minisztérium Pp. hatályosulási munkacsoportjában tett észrevételek és módosítási javaslatok. ${ }^{78}$

Fontos hangsúlyozni, hogy a Pp-t módosító 2020. évi CXIX. törvény 2021. január 1. napjától hatályos, a jogalkotásról szóló 2010. évi CXXX. törvény 15. § (1) bekezdés b) pontja alapján a folyamatban lévő ügyekben is alkalmazni kell a 2021. január 1.

${ }^{6}$ Például 3408/2020. (XI. 13.) AB végzés a polgári perrendtartásról szóló 2016. évi CXXX. törvény 176. § (1) bekezdés j) pontja elleni alkotmányjogi panasz (keresetlevél visszautasítása), 3129/2020. (V. 15.) $A B$ végzés a polgári perrendtartásról szóló 2016 . évi CXXX. törvény 246 . § (1) bekezdés c) pontja és a 248. § (2) bekezdése elleni bírói kezdeményezés (ellenkérelem formalizált benyújtási kötelezettsége)

${ }^{7}$ Miniszteri indokolás a polgári perrendtartásról szóló 2016. évi CXXX. törvény módosításáról szóló 2020. évi CXIX. törvényhez (a továbbiakban: Miniszteri indokolás), Általános indokolás

${ }^{8} \mathrm{Az} \mathrm{OBH}-\mathrm{n}$ belül is felállításra került az új polgári perrendtartást támogató Munkacsoport, melynek tapasztalatairól lásd Gyarmathy Judit - Sándor-Szőke Zsuzsanna: Országos konferencia az új polgári perrendtartás tapasztalatairól; Jogtudományi Közlöny (2019) 11. 467-468. o. 
után megkezdett eljárási cselekményekre. ${ }^{9} \mathrm{Ez}$ a hatályba léptető rendelkezés üdvözlendő, hiszen így a Pp. megalkotásakor szem előtt tartott jogelvek és az esetleg eddig nem érvényesülő jogalkotói szándék hamarabb válik a gyakorlat részévé, illetve kiküszöböli az abból adódó jogértelmezési, joggyakorlati nehézségeket úgy, hogy több egyszerre folyamatban lévő ügyben - amelyek viszont különböző idő́pontokban indultak - ugyanazon eljárási cselekményeknél ne eltérő szabályozáshoz kelljen a jogalkalmazóknak igazodni. Ezzel a jogalkotó fokozza a jogbiztonságot.

\section{A keresetlevél kötelező tartalmi elemeit érintő módosítások}

A polgári per elsőfokú szakasza az osztott perszerkezet bevezetése nyomán tulajdonképpen három létszakra tagolódik: a perfelvételi szak és érdemi tárgyalási szak mellett perindítási szakról is beszélhetünk. ${ }^{10} \mathrm{~A}$ Pp. Perindítás címet viselő XI. Fejezetében a 2020. évi CXIX. törvény elsődlegesen a keresetlevél kötelező tartalmában eszközölt módosításokat.

A Pp. a keresetlevél fogalmát nem határozza meg, csupán funkcióját és tartalmi elemeit illetően ad határozott rendelkezéseket, amelyekből azonban következtetni lehet lényegi sajátosságaira. ${ }^{11}$ A Pp. 169. § (1) bekezdése annyit rögzít, hogy a polgári pert keresetlevéllel kell a felperesnek megindítania az alperes ellen.

A Pp. egyik jelentős újítása volt az 1952-es Pp. szabályozásához képest, hogy a keresetlevél kötelező tartalmi elemeit részletesen szabályozta, hivatkozva arra, hogy a főszabályként jogi képviselővel eljáró felperestől elvárható egy olyan professzionális kezdóirat beterjesztése, mely tartalmaz minden, a per érdemi elbírálásához szükséges adatot és jogszabályi hivatkozást. ${ }^{12}$ A Pp. elkülöníti a keresetlevelet annak mellékleteitől, valamint a keresetlevelet magát bevezető, érdemi és záró tartalmi egységekre bontja. $\mathrm{A}$ bevezető rész - a teljesség igénye nélkül - tartalmazza a felek és képviselőik azonosításához, a velük való kapcsolattartáshoz szükséges adatokat, az érdemi rész magát a keresetet, annak elemeinek megjelölésével és a kereseti tényállításokhoz kapcsolódó bizonyítékokat, végül a záró rész magában foglalja a további, a perelőfeltételek vizsgálatához szükséges adatokat, valamint ezek bizonyítékait. A tagolás a miniszteri indokolás szerint lehetővé teszi a formanyomtatványok alkalmazását, az elektronikus ügyintézést, a laikus fél számára is a kereset szakszerü, hiánytalan megfogalmazását. ${ }^{13} \mathrm{~A}$ szabályozás célja természetesen elsődlegesen nem az volt,

\footnotetext{
${ }^{9}$ A Pp. módosításáról szóló 2020. évi CXIX. törvény 73. §-a határoz meg néhány olyan kivételes módosított szabályt, melyeket csak a törvény hatályba lépését követően indult ügyekben lehet alkalmazni, ilyen például a hatásköri szabályokat érintő módosított rendelkezések.

10 Zsitva Ágnes: Perindítás (kommentár a Pp. 169. §-ához); in: Kommentár a polgári perrendtartásról (Wopera Zsuzsa szerk.), Budapest, Wolters Kluwer, 2019. 395. o.

11 Ébner Vilmos: Keresetlevél; in: A polgári perrendtartás és a kapcsolódó jogszabályok kommentárja I/III. (Varga István szerk.), Budapest, HVG-ORAC, 2018. 610. o.

12 A keresetlevél kötelező tartalmai elemeit mutatja be részletesen Pákozdi Zita: A perindítás és a keresetlevél szabályai az új Pp.-ben; Jogtudományi Közlöny (2017) 7-8. 345-350. o.

${ }^{13}$ Miniszteri indokolás a polgári perrendtartásról szóló 2016. évi CXXX. törvényhez; Általános indokolás,
} 
hogy a felperes elé megvalósíthatatlan követelményeket állítson, hanem hogy lehetőség szerint már itt nyilatkozzon mindenről, melyről tudomása van és a jogvita szempontjából releváns lehet. Ezzel a Pp. az előadások vonatkozásában igyekezett kizárni az ún. "csepegtetési faktort". 14

A gyakorlati tapasztalatok azt mutatták, hogy a Pp. hatályba lépését követően jelentősen lecsökkent a bíróságokon kezdeményezett polgári perek száma. ${ }^{15} \mathrm{~A}$ jogi képviselők nem tudtak kellő mértékben felkészülni a professzionális pervitelre, és a keresetlevél kötelező tartalmi elemeit szabályozó normák tartalmát is eltérően értelmezték a bíróságok, így a keresetlevél visszautasítására a korábban megszokotthoz képest jóval több alkalommal került sor. E problémák orvoslását a Pp. Novella három módon kísérelte meg: elsőként egyszerűsítette a keresetlevél kötelező tartalmi elemeit, másodsorban a keresetlevél megvizsgálását illetően törvényi szinten rögzítette az érdemi vizsgálat tilalmát, és végezetül enyhített a keresetlevél visszautasításának szigorán. ${ }^{16}$

A kezdeti nehézségeket követően a keresetlevél szerkezeti tagolásával kapcsolatban egységessé vált a bírói gyakorlat, a keresetlevélben nem kell feltüntetni az egyes szerkezeti egységek címeit, valamint az egyes szerkezeti egységeken belüli tartalmi elemek előadása sincs formaisághoz vagy időrendi sorrendhez kötve. A kialakult bírói gyakorlatra tekintettel ezt nem volt indokolt a normaszövegben rögzíteni. ${ }^{17}$ Azzal a jogirodalmi állásponttal egyetérthetünk viszont, hogy lényeges, hogy a kötelező tartalmi kellékeknek teljeskörüen és egyértelmúen beazonosítható módon kell szerepelniük a keresetlevélben, erre tekintettel támogatandó annak a jogi képviselők többsége által követett gyakorlatnak a megtartása, hogy a keresetlevél egyes kötelező tartalmi elemeit címmel látják el, vagy legalább az egyes tartalmi elemek előadását az adott tartalmi elem megnevezésével vezetik be (pl. „Keresetem jogalapjaként megjelölöm..."). ${ }^{18}$

A Kúria keresetlevél visszautasításának vizsgálata tárgykörében felállított joggyakorlat-elemző csoportjának összefoglaló véleménye (Vélemény) ${ }^{19}$ alapján egyértelmúen megállapithatóvá vált, hogy a keresetlevél bevezető, érdemi és záró részének melyek azok a tartalmi elemei - amelyek esetében a joggyakorlatban a jogalkotói szándéktól eltérő értelmezés alakult ki és ennek alapján gyakran került sor a keresetlevél visszautasítására -, ahol indokolt a változtatás. A Pp. Novellával bevezetett módosítások - melyek a keresetlevél tartalmát egyszerűsítik a jogalkalmazói tapasztalatokra tekintettel - célja, hogy változtasson a keresetlevél azon tartalmi elemein, amelyek értelmezésével kapcsolatban máig nem

III. Az új törvényi szabályozás legfontosabb újításai 4. pont; BDT2019. 3984.

${ }^{14}$ Bartha Bence: A keresetlevél és az ellenkérelem érdemi része; Közjegyző́k Közlönye (2020) 4. 40. o.

${ }_{15} \mathrm{https} / /$ birosag.hu/hirek/kategoria/birosagokrol/az-allampolgarok-biznak-birosagokban-30-kal-tobbkereset-erkezett-az (utolsó lekérdezés: 2021. 06. 05.)

16 Udvary Sándor: Az első Pp. novella hatása az elsőfokú eljárásra; Jogtudományi Közlöny (2021) 2. 134. o.

17 Miniszteri indokolás a 2020. évi CXIX. törvényhez, Részletes indokolás a 11-12. §-okhoz;

${ }^{18}$ Zsitva Ágnes: Perindítás; in: Kommentár a polgári perrendtartásról (Wopera Zsuzsa szerk.), Budapest, Wolters Kluwer, 2019. 400. o.

${ }^{19} \mathrm{https}$ //www.lb.hu/sites/default/files/joggyak/a_keresetlevel_visszautasitasanak_vizsgalata_osszefoglal o_velemeny.pdf (utolsó lekérdezés: 2021. 04. 05.) 
alakult ki a jogalkotói szándékkal összhangban álló gyakorlat, amely alapján gyakran került sor a keresetlevél visszautasítására, vagy amelyek a felperes számára felesleges adminisztrációs teherként jelentkeztek. ${ }^{20}$ Több esetben a kereseti kérelem határozatlanságát állapították meg és visszautasítási okként értelmezték a keresethalmazatok esetében, vagy az egyes elemek tekintetében elvárták az alapul szolgáló tényelőadás megismétlését, vagy a keresetlevél záró részében a pertárgyérték és az illeték mértékének meghatározása tekintetében szigorú értelmezéshez ragaszkodtak.

A Pp. 170. § (1) bekezdés b) pontja szerint a keresetlevél bevezető részében fel kell tüntetni „a felek nevét, perbeli állását, a felperes azonosító adatait, az alperes azonosító adatai közül legalább a lakóhelyét vagy székhelyét". Ezt a fordulatot a jogalkalmazók túl szigorúan értelmezték és egyes esetekben a közhiteles nyilvántartásból is elérhető adatok hiányát értékelte a bíróság visszautasítási okként. Több esetben a bíróság azon megfontolásból is megkövetelte az alperes valamennyi azonosító adatának megjelölését, hogy az alperesi írásbeli védekezés elmulasztásának a jogkövetkezménye ítéleti hatályú határozat, a bírósági meghagyás kibocsátása, melyhez feltétlenül szükséges az alperes tökéletes azonosíthatósága. Véleményem szerint a Pp. eredeti szövegezéséből is az olvasható ki, de a módosított törvényszöveg már egyértelművé tette, hogy a keresetlevélben az alperesnek a Pp. 7. § (1) bekezdésében rögzített azonosító adatai közül elegendő az alperesi név és lakóhely (vagy székhely) feltüntetése.

A Pp. novelláris módosítása egyértelmüvé tette, hogy a keresetlevél érdemi részében a kereseti kérelem feltüntetése megfelelő, ha a felperes megjelöli azt, hogy milyen döntést kér a bíróságtól. Ez a módosítás összhangban áll a Kúria keresetlevél visszautasításának vizsgálata tárgykörében felállított joggyakorlat elemző csoportjának összefoglaló Véleményében foglaltakkal, mely alapján „A joggyakorlatelemző csoport álláspontja szerint a kereseti kérelem akkor egyértelmú, ha abból kétséget kizáróan megállapítható, hogy a felperes milyen jogvédelmet kér a bíróságtól (azaz megállapítást, marasztalást vagy jogalakítást kér). Erre figyelemmel az egyértelműség az anyagi jogi rendelkezésekre vetítve értelmezhető: a kereseti kérelem alapján nem lehet bizonytalan az, hogy a kérelem milyen jogkövetkezmény kiváltását célozza. Több kereset előterjesztése esetén ki kell derülnie annak is, hogy pontosan hány kereset van, és azoknak milyen a viszonyuk egymással. Mindehhez képest figyelmen kívül kell, hogy maradjon például a petitum nem kellően szabatos megfogalmazása, vagy az, hogy abban esetenként oda nem illő elemek, így például jogszabályhelyek is szerepelnek." ${ }^{21}$ Erre tekintettel a Pp. Novella a Pp. 170. § (2) bekezdésének a) pontját úgy módosította, hogy "a keresetlevél érdemi részében a bíróság döntésére irányuló határozott kereseti kérelmet kell feltüntetni",

${ }^{20}$ Wopera Zsuzsa: Módosul a polgári perrendtartás 2021-től - I.; Jogászvilág (2020. november 18.); https://jogaszvilag.hu/szakma/modosul-a-polgari-perrendtartas-2021-tol-i/ (utolsó lekérdezés: 2021. 04. 10.)

${ }^{21}$ A keresetlevél visszautasításának vizsgálata tárgykörében felállított joggyakorlat elemző csoport összefoglaló véleménye; 21 . o.

https://www.lb.hu/sites/default/files/joggyak/a_keresetlevel_visszautasitasanak_vizsgalata_osszefogla lo_velemeny.pdf (utolsó lekérdezés: 2021. 04. 05.); Miniszteri indokolás a 2020. évi CXIX. törvényhez, Részletes indokolás a 11-12. §-okhoz 
egyértelmüvé téve, hogy a Pp. nem vár el többet a petitum tekintetében, mint az 1952-es Pp. ${ }^{22}$

A Pp. 170. § (2) bekezdésének e) pontjában foglalt bizonyítási indítványok előadására vonatkozó rendelkezés is egyszerüsödik, mert a bizonyítási indítványban a Pp. 275. § (1) bekezdésének módosítása miatt már csak a bizonyítani kívánt tényt és a bizonyítási eszközt kell megjelölni, és nem kell rövid indokolást megfogalmazni arra vonatkozóan, hogy az mennyiben alkalmas a kérdéses tény alátámasztására. ${ }^{23}$

A keresetlevél érdemi részét illetően fontos utalni a Pp. 176. § új (6) bekezdésére is, mely szerint a bíróság a keresetlevél perfelvételre való alkalmasságának vizsgálatakor nem értékelheti a keresetlevél érdemi részében előadott kereseti kérelmet, tényállításokat, jogi érvelést olyan szempontból, mely az ügy érdemi elbírálása körébe tartozik. A felperes által rendelkezésre bocsátott bizonyítékok, a keresetlevélben írt bizonyítási indítványok sem vizsgálhatók olyan értelemben, hogy alkalmasak-e, illetve elegendőek-e a keresetlevélben foglaltak alátámasztására. A Kúria joggyakorlat elemző csoportjának Véleményéből ugyanis kiderült, hogy gyakran vezetett a keresetlevél visszautasításához, hogy a bíróság nem találta határozottnak, pontosnak a kereseti kérelmet vagy a felperes jogi érvelését nem tartotta eléggé meggyőzőnek, a keresetet következetlennek tekintette vagy a felperes tényállitásait kevésnek vagy nem relevánsnak minősítette. ${ }^{24}$

A keresetlevél kötelező tartalmi elemeinek módosítása a legtöbb ponton a záró részre vonatkozó jogszabályi előírásokat érintette. A módosítás a keresetlevél záró részéből is kiiktatta az adminisztrációs terheket növelőnek tekintett tartalmi elemeket. Ezek közül szükséges kiemelni azt a változást, mely szerint a nem természetes személy fél perbeli jogképességét alátámasztó adatokat csak akkor kell előadni, ha az nem rendelkezik közhiteles nyilvántartásból elérhető azonosító adatokkal, mint például a társasház vagy a befektetési alap (nyilvántartási számmal).

A Pp. novelláris módosítása elött a gyakorlatban előfordult, hogy a felperes megjelölte a felperesi cég cégjegyzékszámát, de a nyilvántartó hatóságnál csak annyit, hogy "cégbíróság", hogy melyik törvényszék cégbírósága, azt nem konkretizálta. A Fővárosi Törvényszék Gazdasági Kollégiuma kifejtette, hogy mivel a cégjegyzékszámból megállapítható az, hogy mely törvényszék cégbírósága tartja nyilván a felperesi gazdálkodó szervezetet, ezért a törvényszék megjelölésének

\footnotetext{
22 Wopera Zsuzsa: Módosul a polgári perrendtartás 2021-től - I.; Jogászvilág (2020. november 18.); https://jogaszvilag.hu/szakma/modosul-a-polgari-perrendtartas-2021-tol-i/ (utolsó lekérdezés: 2021. 04. 10.) Érdemes rámutatni arra is, hogy a Kúria új Pp. jogértelmezési kérdéseivel foglalkozó konzultációs testület 47. számú állásfoglalása indokolásában is erre a következtetésre jutott a következők hangsúlyozásával: „A kereseti kérelem határozottságával összefüggésben megfogalmazott feltételek nem azonosíthatók azonban azzal a követelménnyel, hogy a bíróság a kereseti kérelem egyszerű átemelésével, vagy annak tükörszerű átfordításával hozhassa meg a döntését. A jogvédelmi igény azonosíthatósága, valamint a kereseti kérelem alapján meghozható döntés azonosítása azt jelenti, hogy a bíróság számára egyértelmű a megszövegezendő rendelkező rész tartalma".

23 A bizonyítási indítványhoz lásd részletesen Nagy Adrienn: Bizonyítás; in: Kommentár a polgári perrendtartásról (Wopera Zsuzsa szerk.), Budapest, Wolters Kluwer, 2019. 749. o.

24 Wopera Zsuzsa: Módosul a polgári perrendtartás 2021-től - I.; Jogászvilág (2020. november 18.); https://jogaszvilag.hu/szakma/modosul-a-polgari-perrendtartas-2021-tol-i/ (utolsó lekérdezés: 2021. 04. 10.); vö Wopera Zsuzsa: A felek és a bíróság közötti szereposztás a keresetindítás során; Miskolci Jogi Szemle (2020) 1. különszám 361. o.
} 
hiánya önmagában nem vezethet a visszautasítás jogkövetkezményének alkalmazásához. ${ }^{25} \mathrm{~A}$ módosítás ennek a jogalkalmazói gyakorlatnak a fenntartását célozza.

Egy másik ügyben a felperes nem jelölte meg az alperesi társasházat nyilvántartó hatóságot és nyilvántartási számot, a közös képviselő, mint törvényes képviselő kézbesítési címét, ez elsőfokon a keresetlevél visszautasításhoz vezetett, melyet a másodfok is helyben hagyott. Társasház esetében a nyilvántartó hatóság az ingatlannyilvántartást vezető illetékes kormányhivatal, a nyilvántartási szám pedig a helyrajzi szám. Ezek olyan azonosító adatok, melyet a Pp. 7. § (1) bekezdés 2. pontja értelmében fel kell tüntetni a keresetlevél bevezető részében. Az ismert azonosító adat (például a közös képviselő kézbesítési címe) törvényi szófordulat nem azt jelenti, hogy azt a felperesnek ismernie is kell, hanem azt, hogy azt akkor szükséges megjelölni, ha számára hozzáférhető, megismerhető. ${ }^{26}$

A novelláris módosítás értelmében a keresetlevél záró részében nem kell megjelölni a vonatkozó jogszabályhelyet a pertárgyérték meghatározásakor, illetve a bíróság hatáskörének, illetékességének megjelölésekor, csupán a figyelembe vett tényeket kell ismertetni. Ezek a változások üdvözlendők, hiszen e jogintézményeket a Pp. szabályai szerint a bíróság egyébként is hivatalból köteles vizsgálni. A jövőben csak a közhiteles nyilvántartásból elérhető azonosító adat hiányában kell megadni a nem természetes személy fél perbeli jogképességét alátámasztó adatokat. Továbbá nem kell megjelölni a meghatalmazott perbeli képviseleti jogát megalapozó tényeket, jogszabályhelyet, ezt a bíróság a csatolt meghatalmazás alapján vizsgálja. A törvényes képviselőként megjelölt személy tekintetében elegendő előadni, hogy a törvényes képviselő milyen minőségben jár el, például mint ügyvezető, vezérigazgató, szülő, gondnok, gyám; de egyéb adatok közlése nem elvárás.

A Pp. novella a joggyakorlat visszajelzései alapján egyszerüsítette a keresethalmazatokra vonatkozó szabályozást is: a keresetlevélben úgy kell előadni az egyes kereseteket, hogy azokból külön-külön megállapíthatók legyenek a halmazatban érvényesített igények és azok egymáshoz való viszonya. A keresetek azonos tartalmi elemeit, például a tényállításokat ugyanakkor elegendő egyszer előadni. ${ }^{27}$

A keresetlevél kötelező tartalmi elemeit érintő módosítások között szükséges utalni a Pp. 246. §-át érintő változásra: 2021. január 1-től a jogi képviselő nélkül eljáró fél már nem köteles formanyomtatványon előterjeszteni keresetlevelét, írásbeli ellenkérelmét, viszontkereset-levelét vagy a beszámítást tartalmazó iratát. Ugyanakkor a nyomtatványok továbbra is elérhetők és választható alternatívák a jogkeresők számára. ${ }^{28}$

\footnotetext{
${ }^{25}$ Fővárosi Törvényszék 4.Gpkf.75.589/2018/3.

${ }^{26}$ Fővárosi Törvényszék 53.Pkf.637.778/2018/2.

27 Wopera Zsuzsa: Módosul a polgári perrendtartás 2021-től - I.; Jogászvilág (2020. november 18.); https://jogaszvilag.hu/szakma/modosul-a-polgari-perrendtartas-2021-tol-i/ (utolsó lekérdezés: 2021. 04. 10.)

${ }^{28}$ A módosított tartalmú nyomtatványokat a 17/2020. (XII. 23.) IM rendelet tartalmazza
} 


\section{A bíróság hiánypótlási kötelezettségének kiszélesítése}

A Pp. Novella egyik koncepcionális jelentőségű módosítása a 176. §-ban rögzített, a keresetlevél visszautasítási okokat érintette. A Pp. eredeti szövege szerint, ha a jogi képviselővel eljáró felperes által előterjesztett keresetlevél nem tartalmazta a kötelező tartalmi elemeket, illetve alaki kellékeket, vagy a felperes nem csatolta a törvény által előírt kötelező mellékleteket, a bíróság a keresetlevelet visszautasította hiánypótlási felhívás kiadását mellőzve. ${ }^{29} \mathrm{Ez}$ a jogszabályi előirás a gyakorlatban a jogalkotói szándékkal ellentétes hatást váltott ki, illetve ellentétes joggyakorlathoz, jogbizonytalansághoz vezetett.

A Kúrián múködő joggyakorlat elemző csoport Véleményének 23. pontja a Pp. eredeti szövegének 176. § (1) bekezdésének j) pontjában rögzített visszautasítási okkal összefüggésben megállapította, hogy a leggyakoribb hiánypótlás nélküli visszautasítási hivatkozás volt a vizsgált ügyekben. Az is kimutatható, hogy a keresetlevél érdemi része tekintetében a bíróságok leggyakrabban a kereseti kérelem nem határozott voltára hivatkozással éltek a visszautasítás eszközével, ezt követi a tényelőadás és a jogi érvelés hiányosságára, hibájára történő hivatkozás.

A Kúrián működő joggyakorlat elemző csoport Véleménye összegzésképpen rögzítette, hogy a bíróságok a Pp.-nek a kereseti kérelem (petitum) előadásával kapcsolatos követelményét szigorúan értelmezik; azzal szemben gyakran ugyanazt a követelményt támasztják, mint az ítélet rendelkező részével. Ez utóbbit szemléletesen tükrözik az olyan visszautasító végzések, amelyekben a bíróságok szükségtelenül, szinte teljeskörüen hivatkozzák az ítélet rendelkező részével szembeni követelményeket megfogalmazó bírói gyakorlatot. Előfordult, hogy a bíróság az egyébként érthetően megfogalmazott hiánypótlási felhívását mintegy indokolva arról tájékoztatja a felperest, hogy "[a] kereseti kérelmeknek olyan mértékben határozottaknak és szabatosaknak kell lenniük, hogy a keresetnek helyt adó ítélet rendelkező részében változtatás nélkül szerepelhessenek". ${ }^{30} \mathrm{~A}$ bíróságok gyakran csak arra hivatkoznak a visszautasító végzés indokolásában, hogy a keresetlevél a megjelölt tartalmi elemeket nem tartalmazta a "szükséges mértékben", illetve a keresetlevél nem felel meg „a feltételeknek", de a végzésből nem állapítható meg, hogy mi lett volna a "szükséges mérték", vagy miként felelt volna meg „a feltételeknek". Ilyen indokolás mellett a keresetlevél visszautasításának pontos oka és jogalapja nem állapítható meg egyértelmüen. Következésképpen például a keresetlevelet a jogi érvelés hiányossága miatt visszautasító végzések elleni fellebbezésben a felperes alappal hivatkozhatott arra, hogy „....az elsőfokú bíróság nem jelölte meg, hogy konkrétan mely összefüggések hiányát észlelte a keresetlevélben, csupán általános tájékoztatást közölt."

A keresetlevél tartalmi értékelésénél a bíróság gyakran túlterjeszkedik a vizsgálandó és vizsgálható szempontokon, olyan követelményeket támaszt a felperessel szemben, amelyek nem következnek a Pp. 170. §-ának rendelkezéseiből. Az emiatti visszautasítások visszatérő érve, hogy a bíróság a felperes tényállításait „kevésnek", "nem relevánsnak", vagy a jogi érvelés tekintetében „nem elég

\footnotetext{
${ }^{29}$ A Pp. 2018. január 1-én hatályba lépett szövegének 176. § (1) bekezdés j) pontja

${ }^{30}$ Debreceni Járásbíróság 6.P.22.746/2018.
} 
meggyőzőnek" tartja. A bíróságok legjellemzőbben a keresetlevél tényelőadási részében követeltek meg a szükséges és elégséges (az anyagi jog szempontjából releváns) tények előadásán túl további tényeket. Több bíróság a keresetlevél más részébe is gyakran "belelátott" további követelményeket. Előfordult az is, hogy a bíróság lényegében nem tartotta meggyőzőnek a fél jogi érvelését, a minden szempontból következetes keresetet kérte számon a felperesen, érzékelhetően átcsúszva a követelés érdemi elbírálásának tartományába. A tényállítások alátámasztására vonatkozó hiányosságként kezelték a bíróságok több esetben, ha a fél nem tett bizonyítási indítványt, holott ez a félnek továbbra sem kötelezettsége; a bizonyítatlanság jogkövetkezményét nem a keresetlevél megvizsgálása során kell levonni. ${ }^{31}$

A Pp. eredeti szövegéhez kapcsolódóan viszonylag hamar több bírósági határozat is napvilágot látott. A BDT2019. 3984. sz. bírósági döntés II. pontja azt hangsúlyozta, hogy a bizonyítási indítvány előterjesztése nem kötelező eleme a keresetlevélnek, ha annak tartalmából egyértelműen kitünik, hogy a felperes tényállításait a rendelkezésre álló és mellékelt okiratokkal kívánja bizonyítani, továbbá az eljárásnak ebben a szakaszában nincs olyan tény- és jogállítás, ami az okiratokon kívül egyéb bizonyítási indítvány előterjesztését tenné szükségessé. Vagy a BDT2018. 3916. arra hívta fel a figyelmet, hogy a kereseti kérelmet (és az érvényesített jogot) megalapozó tényeket akkor kell a keresetlevélben keresetenként feltüntetni, ha azok az egyes kereseti kérelmek esetében egymástól eltérnek. Ha a professzionális perbeli képviseletre hivatott ügyvéd a keresetlevélhez a meghatalmazását csatolja és ennek tényét a keresetlevélben feltünteti, úgy a perbeli képviseleti joga egyértelmü, ez a képviseleti jogot megalapozó jogszabályhelyek feltüntetését is magában foglalja.

A Pp. Novella lényeges változásokat irányzott elő a keresetlevél hiányosságainak kezelése esetére a jogalkalmazásban tapasztalat problémák kiküszöbölése és a jogkeresők igényérvényesítésének előmozdítása érdekében. A legfontosabb változás, hogy a Novella kibővítette a Pp. 176. § (2) bekezdésében foglalt azon esetek körét, amikor hiánypótlásra történő felhívásnak van helye, így például a keresetlevél tartalmi és alaki hiányosságainak vagy kötelező mellékleteinek hiányossága esetén is. A módosítás ebben az esetben a jogi képviselővel eljáró fél vonatkozásában is kötelezővé tette a hiánypótlásra történő felhívást. A módosítás előírta, hogy a bíróságnak a hiánypótlásra felhívó végzésben a keresetlevél valamennyi hiányosságát teljeskörüen fel kell tüntetnie, és csak a hiánypótlás eredménytelensége esetén van helye visszautasításnak. ${ }^{32}$

A Pp. eredeti szövegezése szerint a bíróságnak csak a keresetlevél visszautasításának tényéről kellett értesítenie az alperest, a módosított Pp. 177. § (1) bekezdésében foglaltak alapján a bíróság az alperest a visszautasítás tényéről a jogerős visszautasító végzés és a keresetlevél megküldésével értesíti. A keresetlevelet visszautasitó végzés alperes részére történő kézbesítése lehetővé

\footnotetext{
31 A keresetlevél visszautasításának vizsgálata tárgykörében felállított joggyakorlat elemző csoport összefoglaló véleménye; 12 . o.

https://www.lb.hu/sites/default/files/joggyak/a_keresetlevel_visszautasitasanak_vizsgalata_osszefoglalo _velemeny.pdf (utolsó lekérdezés: 2021. 04. 05.)

32 Miniszteri indokolás a 2020. évi CXIX. törvényhez, Részletes indokolás a 13. §-hoz
} 
teszi a per kezdőiratának megismerhetőségét a jogerős visszautasitó végzéssel együtt, ez a Pp. 110. § (2) bekezdésében foglalt félegyenlőség elve alapján lehetővé teszi az alperes számára az ellene - sikertelenül - kezdeményezett per kezdőiratának megismerhetőségét a jogerős visszautasító végzéssel együtt. ${ }^{33}$ Egyértelmúvé teszi a módosítás azt is, hogy az alperest a visszautasitó végzés jogerőre emelkedését követően kell értesíteni.

Meglátásom szerint a bíróság hiánypótlási kötelezettségének általánossá tételével egyet visszaléptünk a professzionális pervitelhez képest. Természetesen a $\mathrm{Pp}$. Novellához írt indokolásból érthető, hogy a jogalkotó célja a kapcsolódó nem kívánatos bírói joggyakorlat felszámolása volt. Ezzel a megoldással azonban még az 1952-es Pp.-hez képest is enyhébb eljárási renddel találkozhatunk, hiszen már az 1952-es Pp. is megkövetelte, hogy a jogi képviselő által készített keresetlevél maradéktalanul tartalmazza a törvény által előírt elemeket, ellenkező esetben a bíróság a keresetlevelet idézés kibocsátása nélkül visszautasította. Udvary Sándor álláspontja szerint a Pp. 176. § (1) bek. j) pontjának elejtését, hiánypótlási okká transzformálását indokolatlanná teszi az - az általa is támogatott - módosítás, amely világosan elkülöníti az alaki és érdemi vizsgálat hatókörét. ${ }^{34}$ Jelen szabályozás mellett azonban a jogi képviselő által szerkesztett, ám súlyos vagy bagatell hibákat tartalmazó keresetlevelet sem lehet visszautasítani. E szabálynak azonban a gyakorlatban pozitív hatásai is jelentkezhetnek: lehet, hogy megnő a pereskedési kedv, több jogi képviselő által készített keresetlevél fog érkezni a bíróságokra, és talán a gyakorlat elhagyja azt az eddig követett praktikát, mely szerint azokban a perekben, ahol nem kötelező a jogi képviselet, a fél személyesen eljárva nyújtja be a kezdőiratot - kiküszöbölve azt, hogy a kötelező tartalmi elemek hiánya visszautasításhoz vezessen -, majd a jogi képviselő az első perfelvételi tárgyaláson kapcsolódik be az eljárásba.

\section{A fizetési meghagyásos eljárással összefüggő perek szabályainak módosítása}

Figyelemmel arra, hogy jelen tanulmány Szerzője közjegyző, szükséges figyelmet fordítani a Pp. XVI. Fejezetét érintő módosításokra is, melyek a fizetési meghagyásos eljárással összefüggő perekre tartalmaznak normatív rendelkezéseket.

A fizetési meghagyásos eljárás a közjegyző hatáskörébe tartozó, lejárt pénzkövetelések érvényesítésére szolgáló egyszerüsített polgári nemperes eljárás, melynek eljárási szabályait a fizetési meghagyásos eljárásról szóló 2009. évi L. törvény tartalmazza alapvetően, a Pp. háttérjogszabályként funkcionál, illetve a fizetési meghagyásos eljárásokból perré fordult esetekre tartalmaz speciális szabályokat. Főszabály szerint a hárommillió forintot meg nem haladó pertárgyértékü, polgári jogviszonyból származó lejárt pénzkövetelések kizárólag

\footnotetext{
${ }^{33}$ Miniszteri indokolás a 2020. évi CXIX. törvényhez, Részletes indokolás a 14. §-hoz

34 Udvary Sándor: Az első Pp. novella hatása az elsőfokú eljárásra; Jogtudományi Közlöny (2021) 3. 138. o.
} 
fizetési meghagyás útján érvényesíthetők. ${ }^{35}$ Hangsúlyozandó e szabállyal összefüggésben, hogy a Pp. 254. § (1) bekezdése 2018. január 1. napjától emelte meg a kötelező fizetési meghagyásos eljárások értékhatárát egy millió forintról három millió forintra. A Pp. 254. §-ához füzött miniszteri indokolás szerint tette mindezt a jogalkotó a perré alakuló fizetési meghagyásos eljárások arányára vonatkozó adatokra tekintettel annak reményében, hogy ez csökkentheti a járásbíróságokon induló ügyek mennyiségét. $\mathrm{A}$ jogalkotó célja tehát deklaráltan az ügyek bíróságokról történő elterelése volt a két igényérvényesítési út közötti hangsúly áthelyezésével. ${ }^{36}$ A fizetési meghagyásos eljárásról szóló 2009. évi L. törvényt a Pp. hatályba lépésével összefüggésben módosító 2017. évi CXXX. törvény a fizetési meghagyásos eljárás igénybe vételének felső értékhatárát is módosította, a törvényszéki hatáskörhöz igazította, azaz a korábbi 400 millió forint helyett - mely a kiemelt jelentőségű perek értékhatárához igazodott - 30 millió forintban határozta meg.

A fizetési meghagyásos eljárással kapcsolatos perek szabályait tartalmazó Pp. XVI. Fejezetét ${ }^{37}$ a hatályba lépését követően - a Pp. Novella megalkotása előtt is módosította a jogalkotó. A Magyarország 2020. évi központi költségvetésének megalapozásáról szóló 2019. évi LXVI. törvény a Pp. 259. §-át szabályozta újra, hivatkozva arra, hogy a Pp. 178. § (1) bekezdése alapján a keresetlevél visszautasitása esetén a keresetlevél előterjesztésének joghatásai fennmaradnak, ha a felperes az ügy előzményére hivatkozással, a visszautasító végzés jogerőre emelkedésétől számított harminc nap alatt a keresetlevelet szabályszerüen újra előterjeszti, vagy igényét egyéb úton szabályszerüen érvényesíti. Ez a szabály azonban korábban nem érvényesülhetett a fizetési meghagyásos eljárás perré alakulása során a keresetet tartalmazó irat előterjesztésének hiányosságai miatti eljárás megszüntetés esetében, mivel a Pp. 256. § (1) bekezdése szerint a fizetési meghagyás kibocsátása iránti kérelem előterjesztésének ugyanaz a hatálya, mint a keresetlevél előterjesztésének. Ebből következik, hogy ha a fizetési meghagyásos eljárással indult perben a keresetet tartalmazó irat hiányosságai miatt az eljárás megszüntetésére kerül sor, úgy a felperesnek ismételten fizetési meghagyás kibocsátása iránti kérelmet kell előterjesztenie. Annak érdekében, hogy a keresetet tartalmazó irat hiányosságai orvosolhatóak legyenek, a Pp. vonatkozó szakasza akként módosult, hogy az eljárás megszüntetésére csak akkor kerülhet sor, ha azt megelőzően a bíróság a felperest hiánypótlásra hívta fel, és azt a megadott határidőben a felperes nem teljesítette. Ezzel a módosítással teljes mértékben egyet érthetünk, és tulajdonképpen némileg elöre vetítette a Pp. Novellával bevezetett általános hiánypótoltatási kötelezettséget.

Abban az esetben, ha a felperes olyan követelés tárgyában nyújtja be a

35 Pulinka Mihály: A fizetési meghagyásos eljárással összefüggő perek; in: Kommentár a polgári perrendtartásról szóló 2016. évi CXXX. törvényhez (Wopera Zsuzsa szerk.); Budapest, Magyar Közlöny, 2017, 454. o.

36 Örkényi László: A fizetési meghagyásos eljárás kötelező értékhatára az új polgári perrendtartásban; Közjegyzök Közlönye (2020) 4. 6. o.

${ }^{37}$ A fizetési meghagyásos eljárásokat követő perek szabályozását az új Pp.-ben részletesen elemzi Molnár Judit: Eltűnnek? - A fizetési meghagyásos eljárást követő per egyes szabályainak helyzete az új polgári perrendtartás nyomán; Jogtudományi Közlöny (2017) 10. 463-469. o. 
keresetlevelét, mely vonatkozásában kötelező a fizetési meghagyásos eljárás igénybevétele, a bíróság a keresetlevelet visszautasítja, a perindítás hatályainak beállását követően pedig az eljárást megszünteti. A Pp. Novella a joggyakorlat egységesítését célozta e szabályok átalakításával, tekintettel arra, hogy a bíróságok a Pp. 254. § (3) bekezdésében foglaltak ellenére hivatalból vették figyelembe a fizetési meghagyásos eljárás mellőzését, és erre hivatkozással szüntették meg az eljárást, akkor is, ha a fizetési meghagyásos eljárás mellőzését az alperes nem kifogásolta. A módosítás időbeli határt szabott arra, ameddig ezt a bíróság figyelembe veheti. Ennek értelmében a perfelvétel lezárását követően a bíróság hivatalból sem veheti figyelembe a fizetési meghagyásos eljárás hiányát, és erre hivatkozással az eljárást nem szüntetheti meg sem első-, sem másodfokon. ${ }^{38}$

Amennyiben a kötelezett ellentmondása folytán a fizetési meghagyásos eljárás perré alakul, a felperes a közjegyző felhívásának kézbesítésétől számított 15 napon belül köteles az eljárási illetéket kiegészíteni a peres eljárás illetékének mértékére, illetve keresetét a keresetlevélre, valamint mellékleteire vonatkozó rendelkezéseknek megfelelő tartalmú iratban előterjeszteni a közjegyző által megjelölt bíróságon. Figyelemmel arra, hogy a Pp. Novella a Pp. 246. §-át úgy módosította, hogy a 17/2020. (XII. 23.) IM rendeletben foglalt nyomtatványok használata fakultatív a jogi képviselő nélkül eljáró felek számára, ehhez igazodóan a Pp. 257. §-a is kijelenti, hogy a jogi képviselő nélkül eljáró fél választhatja a nyomtatvány használatát a keresetet tartalmazó irat előterjesztésére. Ezzel áll összhangban a Pp. 259. § (2) bekezdésének korrekciója is, mely az eljárás megszüntetési okok közül kiiktatta azt az esetet, amikor a jogi képviselő nélkül eljáró felperes nem a nyomtatvány használatával terjeszti elő a keresetet tartalmazó iratot.

A Pp. 177. $\S(1)$ bekezdésében a keresetlevelet visszautasító végzés kézbesítésével kapcsolatos szabályok kerültek pontosításra: a bíróság a visszautasitás tényéről az alperest oly módon értesíti, hogy megküldi a jogerős visszautasító végzést és a keresetlevelet. Ehhez igazodik a Pp. 258. §-ának módosítása: ha a bíróság a keresetet tartalmazó iratot visszautasítja, a visszautasítás tényéről - a végzés jogerőre emelkedését követően - az alperest értesíti a keresetet tartalmazó irat megküldésével.

A Pp. Novella a kötelezett ellentmondása folytán perré alakult eljárásban a Pp. 262. § (1) bekezdésében lerövidítette az alperesi ellenkérelem előterjesztésére nyitva álló határidőt: az írásbeli ellenkérelem előterjesztésére vonatkozó határidő 30 nap, melyet az alperes indokolt kérelmére a bíróság legfeljebb 15 nappal meghosszabbíthat. A miniszteri indokolás szerint ez a módosítás a perhatékonyság biztosítása érdekében történt, és a jogalkotó arra tekintettel rövidítette le az írásbeli ellenkérelem előterjesztésére nyitva áló határidőt, hogy a pert olyan nemperes eljárás, a fizetési meghagyásos eljárás előzi meg, ahol az alperes már megismerhette a vele szemben támasztott igényt, arra az általa előterjesztett ellentmondásban már kifejthette az álláspontját, így indokolt a rövidebb határidő meghatározása mind az ellenkérelem előterjesztése, mind annak esetleges meghosszabbítása esetére. ${ }^{39}$ Egyetérthetünk e jogalkotói indokolással és szándékkal, különösen ha arra

\footnotetext{
${ }^{38}$ Miniszteri indokolás a 2020. évi CXIX. törvényhez, Részletes indokolás a 36. §-hoz

${ }^{39}$ Miniszteri indokolás a 2020. évi CXIX. törvényhez, Részletes indokolás a 40. §-hoz
} 
gondolunk, hogy a felperest ennél jóval szigorúbb határidő köti a keresetet tartalmazó irat előterjesztése során.

\section{Záró gondolatok}

A Novella általános célkitüzése a Pp. egyes rendelkezései tekintetében a szabályozás finomítása, a perjogi szabályok egyszerüsítése és rugalmasabbá tétele, valamint a jogkeresők bírósághoz fordulása jogának megkönnyítése volt. E jogalkotói elképzelések a perindítás kapcsán eszközölt módosításokban maximális mértékben tetten érhetők. Azzal, hogy az 1952-es Pp-hez képest a hatályos perjogi kódex részletesen szabályozza a keresetlevél kötelező tartalmi elemeit, a bírósági joggyakorlatban a formalizmus kezdett eluralkodni. Ehhez képest a kötelező tartalmi elemeket egyszerüsítő módosítások rugalmasabbá teszik a keresetlevél megírását, és kiküszöbölik a joggyakorlatban megjelenő nem kívánatos értelmezési tendenciákat. A jogkeresők bírósághoz fordulásának jogát egyértelműen megkönnyíti a keresetlevél visszautasítási okok reformja, a jogi képviselővel eljáró felperesek esetében is a bíróság hiánypótlási kötelezettségének általános jellegü előírása. Igaz, hogy mindez ellentmondani látszik a 2016. évi CXXX. törvénnyel meghirdetett, a felekkel szemben támasztott professzionális pervitel követelményével, ugyanakkor egyértelmüen alkalmas arra, hogy a statisztikai adatok által és a Kúria joggyakorlat elemző csoportja Véleményében kimutatott nem kívánatos joggyakorlatnak gátat szabjon; és nem utolsó sorban, talán a pereskedési kedv is új lendületet vehet Magyarországon. 